\title{
Genetic diversity and population structure of Eurycoma apiculata in Eastern Sumatra, Indonesia
}

\author{
ZULFAHMI $^{1, \boldsymbol{v}}$, PARJANTO ${ }^{2,3}$, EDI PURWANTO ${ }^{2,3}$, AHMAD YUNUS $^{2,3}$ \\ ${ }^{1}$ Department of Agrotechnology, Faculty of Agriculture and Animal Science, Universitas Islam Negeri Sultan Syarif Kasim Riau. Jl. H.R. Subrantas Km. \\ 15, No. 155, Pekanbaru 28293, Riau, Indonesia. Tel.: +62-761-562051, Fax.: +62-761-562051, `email: zulfahmi@uin-suska.ac.id \\ ${ }^{2}$ Department of Agrotechnology, Faculty of Agriculture, Universitas Sebelas Maret. Jl. Ir. Sutami 36A, Surakarta 57126, Central Java, Indonesia \\ ${ }^{3}$ Research Center for Biotechnology and Biodiversity, Universitas Sebelas Maret. J1. Ir. Sutami 36A, Surakarta 57126, Central Java, Indonesia
}

Manuscript received: 24 August 2021. Revision accepted: 25 September 2021.

\begin{abstract}
Zulfahmi, Parjanto, Purwanto E, Yunus A. 2021. Genetic diversity and population structure of Eurycoma apiculata in Eastern Sumatra, Indonesia. Biodiversitas 22: 4431-4439. Information on genetic variation within and among populations of Eurycoma apiculata plants is important to develop strategies for their conservation, sustainable use, and genetic improvement. To date, no information on genetic variation within and among populations of the E. apiculata has been reported. This study aims to assess genetic diversity within and among populations of E. apiculata based on RAPD markers, and to determine populations to collect E. apiculata genetic material for conservation and breeding programs. Young leaves of E. apiculata were collected from six natural populations. Fifteen RAPD primers were used to assess the genetic diversity of each population. The data obtained were analyzed with POPGEN and Arlequin software. The amplification results of 15 selected primers produced 3-16 loci with all primers $100 \%$ polymorphic. At the species level, the mean allele per locus $(\mathrm{Na})$, number of effective alleles $(\mathrm{Ne})$, percentage of polymorphic loci $(P P L)$, Nei's gene diversity index $(\mathrm{He})$ and Shannon information index $(I)$ were $2.000,1.244,100 \%, 0.167$, and 0.286 , respectively. At the population level, the mean values for $\mathrm{Na}, \mathrm{Ne}, \mathrm{PPL}, \mathrm{He}$ and $I$ were $1.393,1.312,39.27 \%, 0.119$, and 0.186 , respectively. The highest value of gene diversity within population $(\mathrm{He}$ ) was found in the Lingga-1 population and the lowest value was found in the Rumbio population. The value of genetic differentiation among populations $\left(G_{S T}\right)$ of $E$. apiculata is 0.284 , consistent with the results of the AMOVA analysis which found that genetic variation among populations was $23.14 \%$, indicates that the genetic variation of E. apiculata was more stored within populations than among populations. The gene flow $(\mathrm{Nm})$ value of E. apiculata was 1.259 migrants per generation among populations. The $\mathrm{Nm}$ value of this species was high category, and could inhibit genetic differentiation among populations. The clustering of E. apiculata population based on the UPGMA dendrogram and PCA was inconsistent with its geographic distribution, reflecting the possibility that genes migration occurred between islands in the past. The main finding of this study was the genetic variation of the $E$. apiculata mostly stored within the population. Therefore, the population with the highest genetic diversity is a priority for in-situ conservation, and collection of E. apiculata genetic material for ex-situ conservation and breeding programs should be carried out minimum from Lingga-1 and Pokomo populations.
\end{abstract}

Keywords: Pasak bumi, genetic variation, gene flow, conservation and breeding strategy

\section{INTRODUCTION}

Eurycoma apiculata, A.W. Benn is a member of the Simaroubaceae family. E. apiculata is only grown in Sumatra island and Malaysian Peninsular in the primary and secondary forest, as well as sandy and acid soils of tropical forest (Nooteboom 1962; Padua et al. 1999; Zulfahmi et al. 2019a). Specifically, existing of E.apiculata in Sumatra island has been reported by Zulfahmi et al. (2019a) and Zulfahmi et al. (2020) in the Riau Province and Riau Islands Province. E. apiculata is one of the pivotal medicinal plants to develop in the future as the source of herbal medicine. Traditionally, the root extract of the E. apiculata is used as a drink to tonic, diarrhea, febrifuge, as well as to decline the boneaches whereas its leaves decoction is used to decline the skin itchiness (Nooteboom 1962; Padua et al. 1999; Zulfahmi et al. 2019a)

Knowledge of genetic variation within and among plant populations is pivotal to develop strategies for optimal management of genetic resources for conservation, sustainable use, and genetic improvement (Medhi et al. 2014; Saini et al. 2018). Besides, genetic variation is needed for plants to adapt to environmental conditions, mainly facing climate change running. Information on genetic diversity within and among populations of $E$. apiculata has not been reported yet. Meanwhile, the natural population of the E. apiculata continues to experience degradation due to forest fires and various exploitative human activities, consequently, this species has been established by the Indonesian government as protected species based on the regulation number of P.20/MENLHK/SETJEN/KUM.1/6/2018. Therefore, an assessment of the genetic diversity of E. apiculata is urgent to be implemented and this scientific report is expected to become a consideration in the compilation of strategy conservation of this species. The eastern Sumatra region is the epicenter of the spreading of E. apiculata reported in Sumatra (Zulfahmi et al. 2018; Zulfahmi et al. 2019a; Zulfahmi et al. 2019b; Zulfahmi et al. 2020) so this area can be considered as a target for E. apiculata conservation areas in the future. 
Information on the diversity of E. apiculata based on morphological markers has been carried out by Zulfahmi et al. (2019b) and Zulfahmi et al. (2020), but the diversity information obtained is not accurate enough to be considered in developing management and breeding strategies for E. apiculata plants because morphological markers are strongly influenced by environmental factors and plant growth (López-Caamal and Tovar-Sánchez 2014; Nadeem et al. 2018; Uslan \& Pharmawati 2020). To overcome the weaknesses of this morphological marker, analysis of diversity using DNA molecular markers is necessary.

DNA-based molecular markers are often used to determine plant genetic diversity. One of the DNA-based markers was Random Amplified Polymorphic DNA (RAPD) (Williams et al. 1990). This marker allows us to obtain large amounts of data on genetic variation within and between populations without prior detailed knowledge of DNA sequences, the number of primers practical unlimited that can be used to provide information about variation across the genome, as well as relatively cheap, fast, and easy compared to other DNA markers (Williams et al. 1990; Weising 2005; Kumari 2014; Dhutmal et al. 2018). RAPD markers have weaknesses, namely low reproductive ability (low reproducibility) and dominant properties (Weising 2005), but it can be overcome through improved laboratory techniques, scoring procedures, and the use of analysis of molecular variance (AMOVA) (Nybom 2004; Weising 2005; Excoffier et al. 2007). Although RAPD has several drawbacks, the use of RAPD markers in population genetic diversity studies has been popular in various of plants species such as Plumbago zeylanica (Panda et al. 2015), Pinus merkusii (Tuong et al. 2016), Cassia tora (Tilwari et al. 2016), Panax ginseng (Wang et al. 2016), Aloe species (Adienge et al. 2019), Silybum marianum (L.) Gaertn (Hamouda 2019). This study aims to assess genetic diversity within and among populations of pasak bumi (E. apiculata) based on the Random Amplified Polymorphic DNA (RAPD) marker, and to determine populations to collect E. apiculata genetic material for conservation and breeding programs.

\section{MATERIALS AND METHODS}

\section{Sample collection}

Young leaves of E. apiculata were taken from six natural populations in Riau and Riau Islands (Eastern Sumatra), Indonesia as shown in figure 1. The longitude and latitute positions, as well as status of each population was displayed in Table 1. The number of samples per population was five individuals. Field distance between individuals collected was at least $20 \mathrm{~m}$. The collected leaves are put into a plastic bag that has given silica gel with a ratio of leaves and silica gel was 1:5 (w/w). Silica gel served to reduce the water contents of the leaves and prevent the samples from being attacked by fungi. The samples were sent to the laboratory and stored in a freezer at $-20^{\circ} \mathrm{C}$ until DNA extraction was carried out.

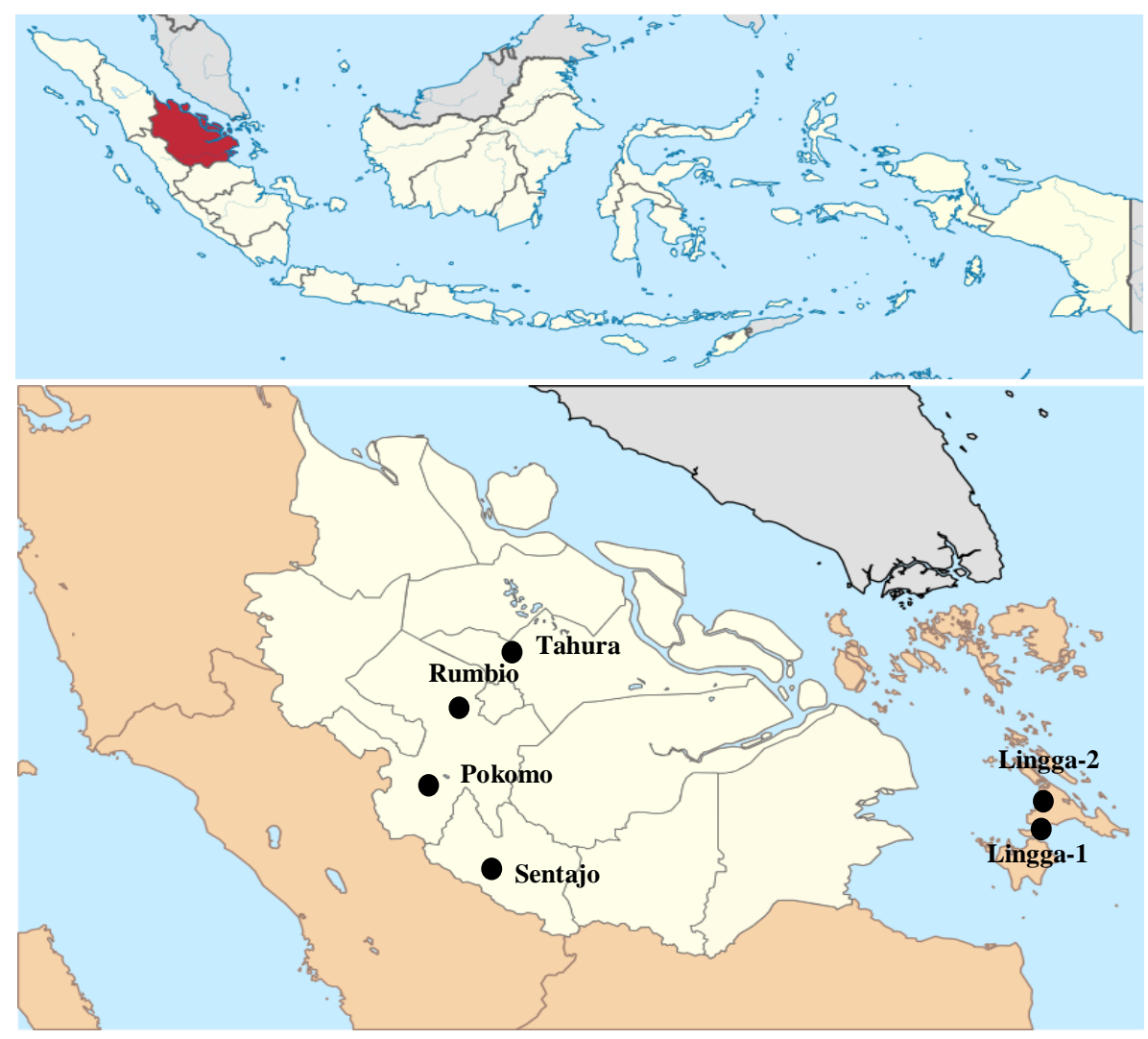

Figure 1. Location of sample collection Eurycoma apiculata in Riau, Indonesia 
Table 1. Characteristic of Eurycoma apiculata research sites in Eastern Sumatra, Indonesia

\begin{tabular}{lccc}
\hline \multicolumn{1}{c}{ Population } & $\begin{array}{c}\text { Status of } \\
\text { research sites }\end{array}$ & Longitude & Latitude \\
\hline Pokomo, Kampar District, Riau Province & Protected forest & $100^{\circ} 57^{\prime} 9^{\prime \prime} \mathrm{E}$ & $0^{\circ} 15^{\prime} 7^{\prime} \mathrm{N}$ \\
TAHURA, Siak District, Riau Province & Forest Park & $101^{\circ} 25^{\prime} 46^{\prime \prime} \mathrm{E}$ & $0^{\circ} 40^{\prime} 21^{\prime} \mathrm{N}$ \\
Rumbio, Kampar District, Riau Province & Protected forest & $101^{\circ} 8^{\prime} 20^{\prime \prime} \mathrm{E}$ & $0^{\circ} 19^{\prime} 40^{\prime \prime} \mathrm{N}$ \\
Lingga-1, Lingga District, Riau Islands Province & Natural forest & $104^{\circ} 40^{\prime} 26^{\prime \prime} \mathrm{E}$ & $0^{\circ} 10^{\prime} 41^{\prime} \mathrm{S}$ \\
Lingga-2, Lingga District, Riau Islands Province & Protected forest & $104^{\circ} 34^{\prime} 52^{\prime \prime} \mathrm{E}$ & $0^{\circ} 12^{\prime} 42^{\prime \prime} \mathrm{S}$ \\
Sentajo, Kuantan Singingi District, Riau Province & Protected forest & $101^{\circ} 34^{\prime} 2^{\prime \prime} \mathrm{E}$ & $0^{\circ} 31^{\prime} 37^{\prime} \mathrm{S}$ \\
\hline
\end{tabular}

\section{DNA extraction}

Genomic DNA of E. apiculata was isolated from leaf tissue using CTAB (cetyltrimethyl ammonium bromide). The isolation procedure followed the method of Doyle and Doyle (1990) with slight modifications (using 0.20\% PVP and $1.0 \%$ mercaptoethanol). The quality DNA was determined by electrophoresis on agarose gel with an agarose concentration of $0.80 \%(\mathrm{w} / \mathrm{v})$ and $1.00 \%(\mathrm{v} / \mathrm{v})$ ethidium bromide. Electrophoresis was carried out using $1 \mathrm{x}$ TAE solution (Tris Acetate EDTA) for 45 minutes at a voltage of 120 volts. The DNA banding patterns were observed under ultraviolet (UV) light and the gel documentation was performed using GelDoc (Biorad). The extracted DNA was stored in a freezer at $-20^{\circ} \mathrm{C}$ until PCR amplification was carried out.

\section{Primer selection and DNA amplification}

Thirty-six (36) random primers were tested and selected for DNA amplification of E. apiculata. Two DNA samples were mixed (bulk), and then used as samples for primer selection. Fifteen (15) primers that gave high polymorphism will be selected and used for DNA amplification of all samples. The PCR machine was set up as follows: initial denaturation for 5 minutes at $95{ }^{\circ} \mathrm{C}$, then followed by 39 cycles with denaturation for 1 minute at 94 ${ }^{\circ} \mathrm{C}$, annealing for 1 minute at $37^{\circ} \mathrm{C}$, extension for 1 minute at $72{ }^{\circ} \mathrm{C}$, and final extension for 10 minutes at $72{ }^{\circ} \mathrm{C}$. The total volume of the PCR reaction was $10 \mu \mathrm{l}$, consisting of $1.30 \mu \mathrm{l}$ of template DNA (5-10 ng), $1.00 \mu \mathrm{l}$ of primer (5 $\mathrm{pmol} / \mu \mathrm{l}), 2.70 \mu \mathrm{l}$ of free RNase water, and $5.00 \mu \mathrm{l}$ of HotStar Taq Master Mix (Qiagen).

The PCR amplification results were separated by electrophoresis on agarose gel with agarose concentrations of $1.50 \%(\mathrm{w} / \mathrm{v})$ at a voltage of 120 volts for 45 minutes. The 100 bp DNA ladder (Vivantis) was also included in electrophoresis as a measurement standard or reference. The DNA banding patterns obtained in agarose were observed under ultraviolet (UV) light and documented using the Gel Doc system (BioRad). Band patterns analysis was performed using Image Lab software (BioRad) version 2.0.1.

\section{Data analysis}

The band patterns obtained from PCR amplification of each sample were scored with value of 1 for band present and 0 for band absent. The scoring results are compiled as binary data to be analyzed with software. The calculated genetic parameters included average number of alleles per locus $(\mathrm{Na})$, Number of effective alleles per locus $(\mathrm{Ne})$, percentage of polymorphic loci $(P P L)$, Nei's gene diversity $\left(H_{e}\right)$, Shannon's information index $(I)$, total gene diversity $\left(H_{T}\right)$, gene diversity within population $\left(H_{S}\right)$, coefficient of genetic differentiation among populations $\left(G_{S T}=\left[H_{T^{-}}\right.\right.$ $\left.\left.H_{S}\right] / H_{T}\right)$, and gene flow among populations $(\mathrm{Nm}=[1-$ $\left.G_{S T}\right] / 4 G_{S T}$ ). All of these parameters were calculated using the POPGEN Software Version 32 (Yeh et al. 1999). Molecular analysis of variance (AMOVA) was also performed to estimate component variation among populations and within populations using ARLEQUIN software version 3.01 (Excoffier et al. 2007). Dendrogram of UPGMA (Unweighted Pair-Group Method Arithmetic Mean) was constructed using NTSYSpc Version 2.00 Software (Rohlf 1998) and principal component analysis (PCA) was performed using SAS software version 9.01 (SAS Institute 2002).

\section{RESULTS AND DISCUSSION}

\section{Primer polymorphism}

Of the thirty-six (36) primers tested, 15 primers were selected due to high polymorphism and clear DNA banding as shown in Table 2. The number of bands generated ranging from 3-16 bands with the size of the DNA bands ranging from 200-2000 bp, depending on the type of primer used, and the plant genotype tested. Seven primers (X-01, OPY-16, P-08, OPY-15, OPD-03, OPY-19, OPJ-20, and $D-11)$ produced a higher number of bands than the other primers.

The percentage of polymorphic bands of each primer is $100 \%$ which indicates that the polymorphism of the genomic DNA of this species is high. Fifteen selected primers resulted in a total number of DNA bands i.e. 132 bands, with an average of 8.8 bands per primer. This result was similar to those reported by Rosmaina and Zulfahmi (2013) in E. longifolia Jack (8.8 bands/primer), higher than those reported by Rosmaina et al. (2015) in E. longifolia Jack ( 2.5 bands/primer), but it was lower than that reported by Razi et al. (2013) on E. longifolia Jack plants in Malaysia (12.8 bands/primer). These differences were caused by the different types of primers used, the plant genotypes and the origin of the population studied. 
Table 2. The selected primer and their sequences, the size and the number of amplified bands of Eurycoma apiculata

\begin{tabular}{|c|c|c|c|c|c|}
\hline Primer name & Sequences & $\begin{array}{c}\text { Fragment size } \\
\text { (bp) }\end{array}$ & Number of band & $\begin{array}{c}\text { Number of fragment } \\
\text { polymorphic }\end{array}$ & $\begin{array}{l}\% \text { fragment } \\
\text { polymorphic }\end{array}$ \\
\hline $\mathrm{X}-01$ & 5'CTCACCGTCC'3 & $300-2000$ & 15 & 15 & 100 \\
\hline OPY-16 & 5'GGGCCAATGT'3 & $300-1200$ & 9 & 9 & 100 \\
\hline P-08 & 5'ACATCGCCCA'3 & $250-1500$ & 12 & 12 & 100 \\
\hline OPY-15 & 5’AGTCGCCCTT‘3 & $300-1500$ & 11 & 11 & 100 \\
\hline Z-13 & 5'GACTAAGCCC'3 & $400-1500$ & 6 & 6 & 100 \\
\hline OPD-03 & 5’GTCGCCGTCA`3 & $350-1100$ & 10 & 10 & 100 \\
\hline OPY-19 & 5'TGAGGGTCCC'3 & $250-650$ & 4 & 4 & 100 \\
\hline OPY-08 & 5'AGGCAGAGCA'3 & $250-900$ & 8 & 8 & 100 \\
\hline OPY-06 & 5'AAGGCTCACC'3 & $600-800$ & 3 & 3 & 100 \\
\hline OPD-08 & 5'GTGCCCCATG'3 & $400-750$ & 5 & 5 & 100 \\
\hline OPJ-20 & 5'AAGCGGCCTC'3 & $290-1200$ & 16 & 16 & 100 \\
\hline D-11 & 5'AGCGCCATTG'3 & $200-1500$ & 16 & 16 & 100 \\
\hline D-08 & 5'GTGTGCCCCA'3 & $350-800$ & 8 & 8 & 100 \\
\hline OPT-07 & 5'GGCAGGCTGT'3 & $250-950$ & 6 & 6 & 100 \\
\hline $\mathrm{K}-02$ & 5'GTCTCCGCAA'3 & $1000-1300$ & 3 & 3 & 100 \\
\hline Mean & & & 8.8 & 100 & $100 \%$ \\
\hline
\end{tabular}

Table 3. The genetic variation index of six populations of Eurycoma apiculata

\begin{tabular}{lccccc}
\hline \multicolumn{1}{c}{ Population } & $\boldsymbol{N a}$ & $\boldsymbol{N e}$ & $\boldsymbol{P P L}(\boldsymbol{\%})$ & $\boldsymbol{H e}$ & $\boldsymbol{I}$ \\
\hline Rumbio & 1.371 & 1.168 & 37.12 & 0.107 & 0.169 \\
Pokomo & 1.439 & 1.222 & 43.94 & 0.135 & 0.208 \\
Sentajo & 1.386 & 1.900 & 38.64 & 0.118 & 0.184 \\
Tahura & 1.303 & 1.195 & 30.30 & 0.112 & 0.166 \\
Lingga-1 & 1.508 & 1.210 & 50.76 & 0.139 & 0.222 \\
Lingga-2 & 1.349 & 1.174 & 34.85 & 0.108 & 0.167 \\
Mean population & 1.393 & 1.312 & 39.27 & 0.119 & 0.186 \\
Species level & 2.000 & 1.244 & 100.00 & 0.167 & 0.286 \\
\hline
\end{tabular}

The PCR amplification results of E. apiculata with primers OPT-07, OPJ-20, and D-11 are shown in Figure 2. There are differences in the number and size of bands produced between individual samples as a result of several events, namely: i) insertion or small deletion of DNA strands that cause changes in the size of the amplification fragment, (ii) deletion occurred at the primer annealing site resulting in loss of fragments or increased fragment size, (iii) insertion of large DNA fragments between the primer annealing sites which exceeds the PCR capability so that no fragments are detected, (iv) nucleotide substitution at one or two primary target sites that affects the annealing process, which results in the presence or absence of polymorphisms or changes the size of the fragments (Weising et al. 2005).

\section{Genetic diversity within populations}

The number of alleles per locus $(\mathrm{Na})$, number of effective alleles per locus $(\mathrm{Ne})$, percentage of polymorphic loci $(P P L)$, Nei's gene diversity $(H e)$, and Shannon's information index $(I)$ of E. apiculata are shown in Table 3. At the species level, the $\mathrm{Na}, \mathrm{Ne}$, and $P P L$ values were 2.00, 1.244 , and $100 \%$, respectively. The $P P L$ value of $E$. apiculata in this study (100\%) was higher than the $P P L$ value of E. longifolia (18.50\%) reported by Loc et al. (2016), and other medicinal plants such as Nepeta kotschyi
Boiss $(P P L=30.80 \%)$ (Hadi et al. 2020), Panax ginseng $(P P L=78.90 \%)($ Wang et al. 2016), and Retama raetam $(P P L=56.09 \%)$ (Abdellaoui et al. 2014).

The value of the Nei's gene diversity $(\mathrm{He})$ and Shannon's information index (I) of E. apiculata species is 0.167 and 0.286 , respectively. The genetic diversity values of $E$. apiculata in this study were lower than the genetic diversity values of the E. longifolia reported by Rosmaina and Zulfahmi (2013) ( $H e=0.29)$, Rosmaina et al. (2015) $(\mathrm{He}=0.181)$, and cross-pollinated species $(\mathrm{He}=0.27)$ (Nybom and Bartish 2000; Nybom 2004). This is closely related to differences in plant genotypes and species distribution. Species with a wide distribution have higher genetic diversity values than species with a narrow distribution ( Levy et al. 2016; Chung et al. 2018; Li et al. 2020). E. longifolia has a wider distribution (covering Sumatra and Kalimantan) than E. apiculata which has a narrow distribution (only in Sumatra) (Nooteboom 1962; Zulfahmi et al. 2019). Moreover, these results are in agreement with our assumption that restricted distribution of E. apiculata and protected species will have lower genetic diversity compared to widely dispersed species. This is due to the influence of directional selection that encourages adaptation to the local environment, inbreeding, and genetic drift that occur in small populations (Gibson et al. 2008). 


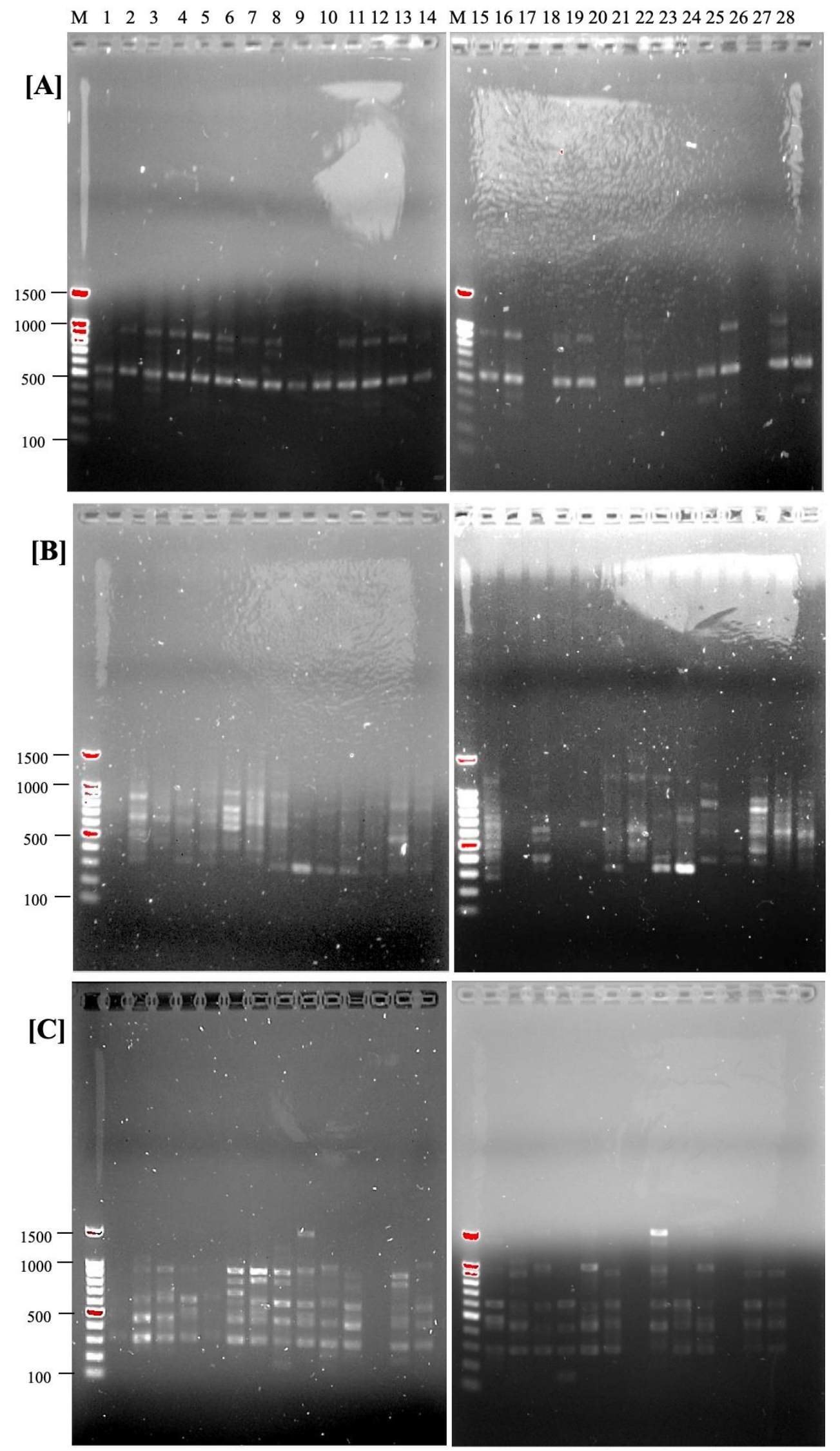

Figure 2. The results of PCR amplification of Eurycoma apiculata used primer OPT-07 [A], OPJ-20 [B], and D-11 [C]. M: DNA ladder, Rumbio population [1-5], Sentajo population [6-10], Pokomo population [11-14], Lingga-1 population [15-19], Tahura population [20-24], and Lingga-2 population[25-28]. 
Table 4. Results of molecular analysis of variants (AMOVA) of Eurycoma apiculata

\begin{tabular}{lccccc}
\hline Source of variation & Degree of freedom & Sum of square & Variance component & Variation $(\%)$ & P value \\
\hline Among populations & 5 & 152.833 & 3.673 & 23.14 & $<0.001$ \\
Within population & 24 & 292.800 & 12.200 & 76.86 & \\
Total & 29 & 445.633 & & & \\
\hline
\end{tabular}

Table 5. The value of the coefficient of genetic distance (below the diagonal) and genetic similarity (above the diagonal) of genetic similarity of Eurycoma apiculata is based on Nei 1978

\begin{tabular}{lcccccc}
\hline \multicolumn{1}{c}{ Population } & Rumbio & Pokomo & Sentajo & Tahura & Lingga-1 & Lingga-2 \\
\hline Rumbio & $* * * *$ & 0.9743 & 0.9511 & 0.9468 & 0.9794 & 0.9564 \\
Pokomo & 0.0260 & $* * * *$ & 0.9668 & 0.9441 & 0.9486 & 0.9413 \\
Sentajo & 0.0502 & 0.0337 & $* * * *$ & 0.9413 & 0.9242 & 0.9030 \\
Tahura & 0.0547 & 0.0575 & 0.0604 & $* * *$ & 0.9614 & 0.9338 \\
Lingga-1 & 0.0208 & 0.0528 & 0.0788 & 0.0394 & $* * * *$ & 0.9729 \\
Lingga-2 & 0.0446 & 0.0605 & 0.1020 & 0.0685 & 0.0275 & $* * *$ \\
\hline
\end{tabular}

At the population level, the number of alleles per locus (Na) and the percentage of polymorphic loci (PPL) of $E$. apiculata ranged from 1.303-1.508 and 30.30\% - 50.76\%, respectively, which the highest value was observed in the population of Lingga-1 and the lowest value was observed in the Tahura population. The number of effective alleles per locus (Ne) ranged from 1.168 (Rumbio population) to 1.222 (Pokomo population). The Nei's gene diversity (He) values of the E. apiculata population ranged from $0.107-$ 0.139 (Table 3 ). The highest value of gene diversity was observed in the Lingga-1 population and the lowest value was observed in the Rumbio population. Populations with high genetic diversity are valuable due to provide diverse gene pools for genetic conservation and plant breeding programs.

The low value of genetic diversity in the Rumbio population compared to other populations is due to a large number of conversions of Rumbio forest areas into rubber plantations by the surrounding community, as the consequences this population is fragmented. The results of this study are in line with those reported by Panda et al. (2015) on Plumbago zeylanica L. plants in which fragmented populations have lower genetic diversity values than other populations that are not fragmented. According to Azman et al. (2020) that populations that have low genetic diversity values indicate that these populations are in a condition of threatening, fragmented, and damaged by human activities. In contrast, The high genetic diversity in the Pokomo population could be caused by several factors, namely i) the genetic diversity has been high from the beginning of the population established, ii) the population has not been a lot disturbed by human activities, so its condition is more maintained, and iii) the occurrence of random mating among individuals resulting in genetic recombination and increasing genetic diversity within population.

If populations of E. apiculata are grouped according to regional distribution (Sumatra and Riau Islands), the average value of genetic diversity of the E. apiculata population from the Riau Islands region (Lingga-1 and
Lingga-2) is 0.124 , higher than the population genetic diversity of E. apiculata from Sumatra region (0.118). This result contradicts the general hypothesis that the plants genetic diversity of the mainland populations is higher than that of the island populations. But this result is in line with those reported by García-Verdugo et al. (2015) on the Periploca laevigata plant who found that genetic diversity in the island populations was higher than in the mainland populations.

Genetic diversity is important for plants to adapt to changes in environmental conditions so that plants can survive for a long time. Lack of amount of genetic diversity will limit the ability of plants to cope with environmental changes and their role in the ecological and evolutionary development of the biosphere (Runo et al. 2004) so that the maintenance of genetic diversity is considered important as a carrier of diversity for ecological adaptation and microevolution.

\section{Genetic differentiation and population structure}

The value of genetic differentiation among populations $\left(G_{S T}\right)$ of E. apiculata was $0.284\left(H_{T}=0.167, H_{S}=0.120\right)$, indicates that $28.40 \%$ of the total genetic diversity is stored among populations and $71.60 \%$ of the total genetic diversity existed within the population. The results of the analysis of molecular variance (AMOVA) also confirmed that the genetic diversity of E. apiculata is more stored within population than among populations, in which the percentage of genetic diversity among populations and within the population of E. apiculata is $23.14 \%$ and $76.86 \%$, respectively (Table 4 ). AMOVA results showed a highly significant difference $(\mathrm{P}<0.001)$ in genetic differentiation among populations. The high genetic diversity stored within the population is due to the fact that E. apiculata is a cross-pollinated species, which pollination is assisted by insects and bees (Zulfahmi et al. 2020) so that random mating can occur among individuals and results in high genetic variability within the population. The high genetic diversity within population will be a consideration in developing a conservation strategy and selecting genetic 
material to build a breeding population. The $G_{S T}$ value of $E$. apiculata in this study was lower than the average $G_{S T}$ of the E. longifolia (0.31) reported by Rosmaina \& Zulfahmi (2013), Panax ginseng plant $\left(G_{S T}=0.430\right)$ (Wang et al. $2016)$ and higher than cross-pollinated plants $\left(G_{S T}<23 \%\right)$ (Nybom 2004) and other species such as Pinus merkusii $\left(G_{S T}=0.186\right)$ (Tuong et al. 2016), and Retama raetam $\left(G_{S T}\right.$ $=0.260)$ (Abdellaoui et al. 2014).

According to Nei (1978), the $G_{S T}$ value can be grouped into three categories, low if the $G_{S T}$ value is $<0.05$, moderate if the $G_{S T}$ value is 0.05-0.15), and high if the $G_{S T}$ value is $>0.15$. Based on this category, the $G_{S T}$ value of the E. apiculata in this study is the high category. The high $G_{S T}$ value indicates that gene flow among populations of $E$. apiculata through seeds and pollen is limited. The seed size of E. apiculata is relatively large and heavy so that the spread of seeds is only limited to the forest floor near the mother tree, reflected most of seedlings found around the mother tree. The gene flow of the E.apiculata through the pollen depends on the pollinator (bees and beetles). Rader et al. (2011) reported the ability of beetles carried pollen of Brassica rapa L as far as 400 from a pollen source while Tani et al. (2009) reported that pollen dispersal distance of Shorea parvifolia Dyer and Shorea leprosula Miq is about 250-450 $\mathrm{m}$ and more than $700 \mathrm{~m}$, respectively, from the mother tree in the tropical forests of Peninsular Malaysia.

Gene flow is one of the important parameters that determine plant genetic diversity. Gene flow is the transfer of genes within and among populations. This gene flow is determined by pollinators, seed dispersers, stand density, flowering phenology, plant sex distribution, outcrossing rate and inbreeding depression (Dick et al. 2008). The gene flow value $(\mathrm{Nm})$ of $\mathrm{E}$. apiculata in this study was 1.259 migrants per generation among populations. According to Govindaraju (1989) that the value of gene flow can be categorized into three levels, namely low if $N m<0.25$, moderate if $0.25<N m<0.99$, and high if $N m>1$. Based on these categories, the value of gene flow E. apiculata is the high category. The gene flow value of this study was higher than that reported by Rosmaina and Zulfahmi (2013) on E. longifolia $(\mathrm{Nm}=1.11)$ and other medicinal plants

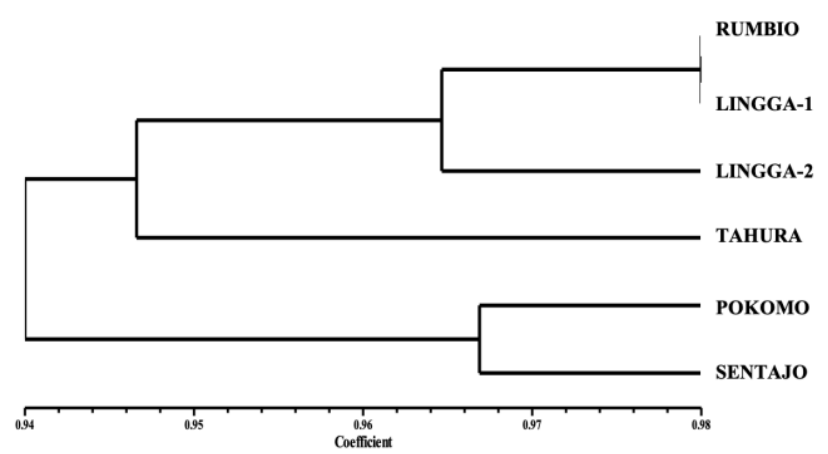

Figure 3. UPGMA dendrogram for the population of E. apiculata based on the genetic similarity value of Nei 1978 such as Zanthoxylum spp $(N m=1.31)($ Medhi et al. 2014), Retama raetam $(\mathrm{Nm}=1.42)$ ) (Abdellaoui et al. 2014).

Theoretically, a high $\mathrm{Nm}$ value is considered sufficient to inhibit genetic drift and prevent genetic differentiation between populations, whereas $\mathrm{Nm}$ value $<1$ is not sufficient to counteract the effects of genetic drift, which is the dominant factor causing genetic differentiation between populations ( $\mathrm{Li}$ et al. 2018). Based on the value of gene flow in this study, genetic drift has not been the dominant factor influencing the genetic structure of the populations of the E. apiculata. However, the population of $E$. apiculata is currently in a threatening condition due to habitat fragmentation which will slowly affect their genetic structure. High values of $N m$ between populations of $E$. apiculata also indicate that geographic barriers do not significantly affect gene flow, but geographic distances may influence genetic relationships.

Values of genetic similarity and genetic distances between populations of E. apiculata are shown in Table 5 . The value of genetic similarity between populations of $E$. apiculata ranged from $0.9030-0.9794$, with the highest value of genetic similarity observed between the Lingga-1 population and the Rumbio population, while the lowest genetic similarity value was found between the Sentajo and Lingga-2 populations (Table 5). The Lingga-1 and Lingga2 populations have closer genetic similarities to the Rumbio population than other populations from Sumatra.

The results of the UPGMA dendrogram based on genetic similarity Nei (1978) grouped the E. apiculata populations into two main groups at the 0.945 or $94.50 \%$ genetic similarity, namely the first group consisted of Pokomo and Sentajo populations, while the second group consisted of Tahura, Lingga-2, Rumbio, and Lingga-1 populations. At the genetic similarity of $0.96(96.00 \%)$, the second group was divided into two sub-groups, namely the first sub-group consisted of the Tahura population, the second sub-group consisted of the Lingga-2, Rumbio, and Lingga-1 populations (Figure 3).

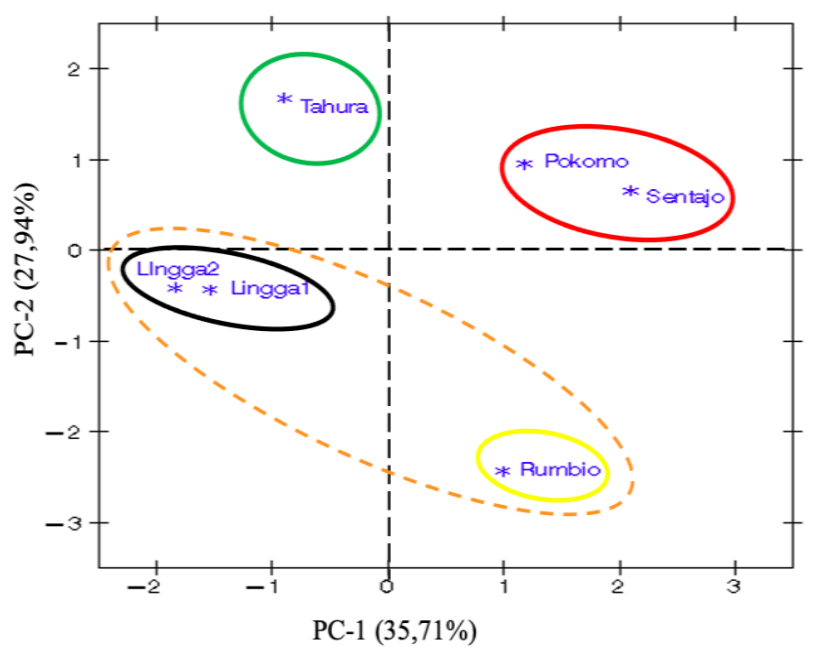

Figure 4. Scatter plot Eurycoma apiculata population based on PCA 
PCA analysis was also performed to better understand the genetic structure of the population of species. The PCA results of E. apiculata showed that the first and second main components (PC-1 and PC-2) explained the cumulative variation percentage of $63.64 \%$ of the total variation, in which the first main component (PC-1) explained $35.71 \%$ of the total variation with an eigenvalue of 2.67 while the second main component (PC-2) explained $27.94 \%$ of the total variation with an eigenvalue of 2.09 . According to Banda \& Kumarasamy (2020), the acceptable threshold value for the percentage of the cumulative variation of PCA is greater than $60 \%$. The percentage of cumulative variation of $\mathrm{PC} 1-$ and $\mathrm{PC}-2$ of $E$. apiculata $(63.64 \%)$ in this study was above this threshold and was higher than the percentage of cumulative variation of PC-1 and PC-2 with RAPD markers reported by Dillipan et al. al. (2017) on seaweed (58.55\%), Tuong et al. (2016) in Pinus merkusii $(42.95 \%)$. Scatter plot PC-1 and PC-2 of PCA grouped the population of E. apiculata into four groups, namely the first group was the population of Pokomo and Sentajo, the second group was the Tahura population, the third group was the Rumbio population, and the fourth group was the Lingga-1 population and the population Linga-2 (Figure 4).

The results of the UPGMA dendrogram and PCA scatter plot of E. apiculata exhibited that population clustering does not reflect the geographic distribution of the species. Population groupings not reflecting geographic distribution reported by Zulfahmi et al. (2015) on Meranti species (Shorea spp.), Zulfahmi et al. (2020) on E. apiculata, and Zulfahmi et al. (2021) on E. longifolia. A mixture of population from the Riau Islands and the population from the island of Sumatra in one group indicated the gene flow of the E. apiculata between the Sumatra island (Rumbio) and the Riau Islands (Lingga-1 and Lingga-2). This gene flow probably occurred during the glacial period, in which the islands of Sumatra and Riau Islands were still joined which were connected by a stretch of savanna forest (Slik et al. 2011; Wurster et al. 2019).

In conclusion, the fundamental genetic information regarding the natural population of E. apiculata was obtained using RAPD marker in this study, in which the mean value of genetic diversity within the population was 0.120 , the value of genetic differentiation among populations $\left(G_{S T}\right)$ was 0.284 , as well as geographic patterns of genetic variation among populations, were also detected. These genetic findings have important implications for conservation and breeding programs. The Lingga-1 and Pokomo populations can be selected as a target for the collection of $E$. apiculata genetic material for ex-situ conservation and breeding programs. Finally, this study suggests using molecular markers with high variability in future studies to obtain detailed genetic information that more facilitates the conservation and management of genetic resources of E. apiculata.

\section{ACKNOWLEDGEMENTS}

The authors would like to thank to Educational Fund Management Board (LPDP), Ministry of Finance, Republic of Indonesia, for funding this research with contract number of PRJ-3/LPDP.4/2020. The authors thank to Riau Province of Forestry services, Forest Park of Sultan Syarif Hashim Minas, Lingga District Agriculture and Plantation Services, KPHP Kuantan Singingi, and Head of Sentajo Village - Kuantan Singingi for permission of collecting material in the field.

\section{REFERENCES}

Abdellaoui R, Yahyaoui F, Neffati M. 2014. Population structure and genetic diversity of a medicinal plant species Retama raetam in Southern Tunisia. Pak J Biol Sci 17: 182-189. DOI: 10.3923/pjbs.2014.182.189

Adienge A, Muturi G, Nadir S, Gicheru J, Kinyua J, Ngaira J. 2019. Genetic diversity and population structure of three commercial indigenous Aloe species in selected ASALs of Kenya. J Plant Sci Mol Breed 8 (1): 1-9. DOI: 10.7243/2050-2389-8-1

Azman A, Ng K-K-S, Ng C-H, Lee C-T, Tnah L-H, Zakaria N-F, Mahruji $\mathrm{S}$, et al. 2020. Low genetic diversity indicating the threatened status of Rhizophora apiculata (Rhizophoraceae) in Malaysia: Declined evolution meets habitat destruction. Sci Rep 10: 19112. DOI: 10.1038/s41598-020-76092-4

Banda TD, Kumarasamy M. 2020. Application of multivariate statistical analysis in the development of a surrogate water quality index (WQI) for South African watersheds. Water 12: 1584. DOI: $10.3390 /$ w12061584

Chung MY, López-Pujol J, Son S, Suh GU, Yukawa T, Chung MG. 2018. Patterns of genetic diversity in rare and common orchids focusing on the Korean Peninsula: Implications for conservation. Bot Rev 84: 125. DOI: $10.1007 / \mathrm{s} 12229-017-9190-5$

Dhutmal RR, Mundhe AG, More AW. 2018. Molecular marker techniques: A review. Int J Curr Microbiol Appl Sci 6: 816-825.

Dick CW, Hardy OJ, Jones FA, Petit RJ. 2008. Spatial scales of pollen and seed-mediated gene flow in tropical rain forest trees. Trop Plant Biol 1: 20-33. DOI: 10.1007/s12042-007-9006-6

Doyle JJ, Doyle JL. 1990. Isolation of plant DNA from fresh tissue. Focus 12: $39-40$.

Excoffier L, Laval G, Schneider S. 2007. Arlequin (version 3.0): An integrated software package for population genetics data analysis. Evol Bioinform Online 1: 47-50.

García-Verdugo C, Sajeva M, Mantia TL, Harrouni C, Msanda F, Caujapé-Castells J. 2015. Do island plant populations really have lower genetic variation than mainland populations? Effects of selection and distribution range on genetic diversity estimates. Mol Ecol 24: 726-741. DOI: 10.1111/mec.13060

Gibson JP, Rice SA, Stucke CM. 2008. Comparison of population genetic diversity between a rare, narrowly distributed species and a common, widespread species of Alnus (Betulaceae). Am J Bot 95: 588-596. DOI: 10.3732/ajb.2007316

Govindaraju DR. 1989. Variation in gene flow levels among predominantly self-pollinated plants. J Evol Biol 2: 173-181. DOI: 10.1046/j.1420-9101.1989.2030173.x

Hadi N, Shojaeiyan A, Sefidkon F, Jafari AA, Mišić D, Banjanac T, Šiler B. 2020. Assessment of infraspecific genetic diversity in Nepeta kotschyi Boiss., a native Iranian medicinal plant. J Agric Sci Technol 22 (5): 1327-1334.

Hamouda M. 2019. Molecular analysis of genetic diversity in population of Silybum marianum (L.) Gaertn in Egypt. J Genet Eng Biotechnol 17: 12. DOI: 10.1186/s43141-019-0011-6

Kumari N, Thakur SK. 2014. Randomly amplified polymorphic DNA-A brief review. Am J Anim Vet Sci 9: 6-13. DOI: 10.3844/ajavsp.2014.6.13

Levy E, Byrne M, Coates DJ, Macdonald BM, McArthur S, Leeuwen S van. 2016. Contrasting influences of geographic range and distribution of populations on patterns of genetic diversity in two 
sympatric pilbara acacias. PLoS One 11: e0163995. DOI: 10.1371/journal.pone.0163995

Li S, Gan X, Han H, Zhang X, Tian Z. 2018. Low within-population genetic diversity and high genetic differentiation among population of the endangered plant Tetracentron sinense Oliver revealed by inter-simple sequence repeat analysis. Ann For Sci 75: 74. DOI: 10.1007/s13595-018-0752-4

Li S, Liu S-L, Pei S-Y, Ning M-M, Tang S-Q. 2020. Genetic diversity and population structure of Camellia huana (Theaceae), a limestone species with narrow geographic range, based on chloroplast DNA sequence and microsatellite markers. Plant Diver 42: 343-350. DOI: 10.1016/j.pld.2020.06.003

Loc NH, Lan P, Thanh L, Thang N, Thang NV, Luong NN, Đức TM, Yen VT, Hoi N, Tu HTN, Doanh PH. 2016. An investigation on the distribution and genetic diversity of Eurycoma longifolia Jack, and in vitro conservation of this valuable medicinal tree in Thua Thien Hue, Vietnam. Plant Cell Biotechnol Mol Biol 17: 226-234.

López-Caamal A, Tovar-Sánchez E. 2014. Genetic, morphological, and chemical patterns of plant hybridization. Rev Chil de Hist Nat 87: 114. DOI: $10.1186 / \mathrm{s} 40693-014-0016-0$

Medhi K, Sarmah DK, Deka M, Bhau BS. 2014. High gene flow and genetic diversity in three economically important Zanthoxylum Spp. of Upper Brahmaputra Valley Zone of NE India using molecular markers. Meta Gene 2: 706-721. DOI: 10.1016/j.mgene.2014.09.009

Nadeem MA, Nawaz MA, Shahid MQ, Doğan Y, Comertpay G, Yıldız M, Hatipoğlu R, Ahmad F, Alsaleh A, Labhane N, Özkan H, Chung G, Baloch FS. 2018. DNA molecular markers in plant breeding: Current status and recent advancements in genomic selection and genome editing. Biotechnol Biotechnol Equip 32: 261-285. DOI 10.1080/13102818.2017.1400401

Nei M. 1978. Estimation of average heterozygosity and genetic distance from a small number of individuals. Genetics 89: 583-590. DOI: $10.1093 /$ genetics/89.3.583

Nooteboom HP. 1962. Simaroubaceae. In: Van Steenis CGGJ (Ed.), Flora Malaysiana. Wolters Noordhoof, Groningen.

Nybom H. 2004. Comparison of different nuclear DNA markers for estimating intraspecific genetic diversity in plants. Mol Ecol 13: 1143-1155. DOI: 10.1111/j.1365-294X.2004.02141.x

Nybom H, Bartish I. 2000. Effects of life history traits and sampling strategies on genetic diversity estimates obtained with RAPD markers in plants. Perspect Plant Ecol Evol Syst 3: 93-114. DOI: 10.1078/1433-8319-00006

Padua L, Bunyapraphatsara N, Lemmens R. 1999. Plant Resources of South-East Asia. Medicinal and Poisonous Plants I. Backhuys Publisher, Leiden.

Panda S, Naik D, Kamble A. 2015. Population structure and genetic diversity of the perennial medicinal shrub Plumbago. AoB Plants 7: plv048. DOI: 10.1093/aobpla/plv048

Rader R, Edwards W, Westcott DA, Cunningham SA, Howlett BG. 2011 Pollen transport differs among bees and flies in a human-modified landscape. Divers Distrib 17: 519-529. DOI: 10.1111/j.1472 4642.2011.00757.x

Razi ARM, Abdul-Aziz A, Aziz R. 2013. Relationships between Malaysians cultivars of tongkat ali (Eurycoma longifolia Jack) obtained through RAPD analysis. Int J Biotechnol Wellness Ind 2: 45-50. DOI: 10.6000/1927-3037.2013.02.01.7

Rosmaina R, Azhari R, Zulfahmi Z. 2015. Genetic diversity of Eurycoma longifolia Jack using random amplified polymorphic DNA (RAPD) marker in Forest Reserve of Kenegerian Rumbio, Indonesia. Malays Appl Biol 44: 73-80.

Rosmaina R, Zulfahmi Z. 2013. Genetic diversity of Eurycoma longifolia Jack based on random amplified polymorphic DNA marker. Jurnal Manajemen Hutan Tropika 19: 138-144. DOI: 10.7226/jtfm.19.2.138
Saini A, Hegde S, Hegde HV, Kholkute SD, Roy S. 2018. Assessment of genetic diversity of Saraca asoca (Roxb.) De Wilde: A commercially important, but endangered, forest tree species in Western Ghats, India. New Zealand J For Sci 48: 17. DOI: 10.1186/s40490-0180122-x

SAS Institute. 2002. SAS/STAT User's Guide. Version 9.00. SAS Institute Inc, Cary, NC, USA.

Tani N, Tsumura Y, Kado T, Taguchi Y, Lee SL, Muhammad N, Ng KKS, Numata S, Nishimura S, Konuma A, Okuda T. 2009. Paternity analysis-based inference of pollen dispersal patterns, male fecundity variation, and influence of flowering tree density and general flowering magnitude in two dipterocarp species. Ann Bot 104: 14211434. DOI: $10.1093 / \mathrm{aob} / \mathrm{mcp} 252$

Tilwari A, Chauhan D, Sharma R, Singh R. 2016. Assessment of genetic variations among medicinal plant Cassia tora from different geographic regions of Central India using RAPD markers. J Med Aromatic Plants 5 (6): 1-7. DOI: 10.4172/2167-0412.1000276

Tuong HM, Giang NT, Ha CH, Son LV. 2016. Genetic variation within and between three Vietnamese pine populations (Pinus merkusii) using random amplified polymorphic DNA (RAPD) markers. Afr J Biotechnol 15: 1641-1647. DOI: 10.4314/ajb.v15i30

Uslan U, Pharmawati M. 2020. Genetic diversity of Sterculia quadrifida in Kupang, Indonesia based on RAPD (Random Amplified Polymorphic DNA) markers. Biodiversitas 21: 3407-3414. DOI: $10.13057 /$ biodiv/d210766

Wang S, Chen X-L, Han F-B, Li R-S, Li G, Zhao Y, Xu Y-H, Zhang L-X. 2016. Genetic diversity and population structure of ginseng in China based on RAPD analysis. Open Life Sci 11: 387-390. DOI: 10.1515/biol-2016-0051

Weising K. 2005. DNA Fingerprinting in Plants: Principles, Methods, and Applications 2nd Ed. Taylor and Francis Group, Boca Raton.

Williams JG, Kubelik AR, Livak KJ, Rafalski JA, Tingey SV. 1990. DNA polymorphisms amplified by arbitrary primers are useful as genetic markers. Nucleic Acids Res 18: 6531-6535. DOI: 10.1093/nar/18.22.6531

Yeh F, Yang R, Boyle T. 1999. POPGEN Version 1.31: Microsoft Window Based for Population Genetic Analysis. Edmonton, Alberta, Canada: Department Renewable Resources, University of Alberta.

Zulfahmi Z, Mahfira U, Siregar U, Siregar I, Yunanto T. 2015. Comparison of levels of chloroplast DNA diversity of two Shorea species with contrasting geographical distribution. Asia Pac J Mol Biol Biotechnol 23: 291-302. DOI: 10.21307/apjmbb-2015-009

Zulfahmi, Rahmasari A, Irfan M, Rosmaina, Nazir M. 2018. Chromosome numbers and karyotypes of Eurycoma longifolia Jack and Eurycoma apiculata A. W. Benn (Simaroubaceae). Pak J Biotechnol 15: 969973.

Zulfahmi Z, Aryanti E, Rosmaina R. 2019a. New Record of Eurycoma apiculata A.W. Benn (Simaroubaceae) from Forest Reserve of Kenegerian Rumbio, Riau, Indonesia. Berita Biologi 18: 365-371. DOI: $10.14203 /$ beritabiologi.v18i3.3683

Zulfahmi, Aryanti E, Rosmaina, Suherman, Nazir M. 2019b. Differentiation of two species of pasak bumi (Eurycoma Spp) based on leaf morphometric. Plant Arch 19: 265-271.

Zulfahmi Z, Purwanto E, Parjanto, Yunus A. 2020. Phenotypic diversity and plasticity index of Eurycoma apiculata populations in Eastern Sumatra, Indonesia based on leaves morphology. Biodiversitas 21 (7): 2923-2934. DOI: 10.13057/biodiv/d210708

Zulfahmi, Parjanto, Purwanto E, Yunus A. 2021. The morphology and density of pasak bumi (Eurycoma longifolia, Jack) leaf trichomes in six natural populations in Indonesia. IOP Conf Ser Earth Environ Sci 637: 012031. DOI: 10.1088/1755-1315/637/1/012031 